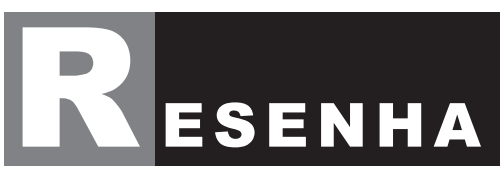




\section{LEVITSKY, Steven; ZIBLATT, Daniel. Como as democracias morrem. Rio de Janeiro: Zahar, 2018. 272 p. ISBN - 13: 978- 8537818008.}

\section{Anderlany Aragão dos Santos}

Doutoranda em Desenvolvimento Sustentável na Universidade de Brasília, mestre em Desenvolvimento e Meio Ambiente e cientista ambiental. ID ORCID: http://orcid.org/0000-0002-9489-6383.

Steven Levitsky e Daniel Ziblatt, ambos professores na Faculdade de Governo e Ciências Políticas da Harvard University, escreveram uma fluida e essencial obra sobre o cenário político global atual. Os autores, especialistas em democratização, partidos políticos e colapsos democráticos, reuniram em Como as democracias morrem aspectos que caracterizam cenários de derrocada de regimes democráticos. A vigente ascensão de tais cenários e a consequente necessidade de compreendê-los tornam esta obra essencial. A fluidez é justificada pela forma didática de tratamento dos assuntos, que certamente não são facilmente compreensíveis. Assim, mesmo para quem não entende o denso espectro dos temas políticos, o texto não é cansativo, tampouco complicado. Levitsky e Ziblatt trazem esses assuntos acompanhados de metáforas e analogias que facilitam a assimilação. Ao retornarem constantemente aos casos narrados de líderes autoritários, os autores oferecem um panorama geral sobre os regimes tratados, mesmo que os leitores não sejam familiarizados com os governos analisados.

O prefácio da edição brasileira, escrito pelo cientista político Jairo Cesar Marconi Nicolau, não só contextualiza a obra historicamente - relatando o fracasso da democratização dos países que promoveram a Primavera Árabe e a reversão de experiências democratizadoras africanas, asiáticas e do Leste Europeu - mas também a aproxima do contexto brasileiro. Neste sentido, Nicolau coloca que o país atravessa, desde 2013, um período turbulento, embora não chegue a mencionar a ascensão do atual presidente, Jair Bolsonaro. Esta leitura coube ao próprio Levitsky que, em visita ao Brasil durante o período eleitoral, afirmou que Bolsonaro é uma figura autoritária que pode comprometer a democracia (BULLA, 2018; FERRAZ, 2018; FRABASILE, 2018). 
Apesar da breve análise de Levitsky durante a sua visita, o caso brasileiro não é abordado no livro, que tem como principal objeto de análise as instituições democráticas norte-americanas. Esta escolha é fundamentada por dois pontos: a histórica influência dos Estados Unidos da América (EUA) sobre os processos políticos de outras nações (LAW; VERSTEEG, 2012) e a ascensão política de Donald Trump, que os autores colocam como um líder potencialmente autoritário.

Assumindo, portanto, o risco de colapso da democracia norte-americana em virtude da eleição de um governo impositivo, Levitsky e Ziblatt buscam, logo no primeiro capítulo, diagnosticar padrões comportamentais desses líderes avessos à democracia, identificando quatro sinais de alerta: 1) rejeição às regras democráticas (buscam minar a legitimidade das eleições ou da Constituição, por exemplo); 2) negação da legitimidade dos oponentes políticos (descrevem seus oponentes como criminosos ou ameaças à ordem existente); 3) tolerância e encorajamento à violência (têm laços com milícias, guerrilhas e forças paramilitares e/ou elogiam a violência política ocorrida no passado ou em outros países); e 4) disposição a restringir liberdades civis de opositores (defendem leis de calúnia e difamação e/ou leis que limitem protestos ou críticas ao governo).

Nos quatro capítulos seguintes, os autores trazem exemplos de líderes políticos de vários países, os quais atendem aos padrões levantados pelo supracitado checklist. Explicam, portanto, a derrocada democrática em países como Bélgica, Finlândia, Chile e Venezuela a partir da ascensão de demagogos por vias constitucionais. Desta forma, o esforço dos autores focaliza a desvinculação da democracia da ordem constitucional, tema tratado na obra Competitive Authoritarianism: Hybrid Regimes after the Cold War (LEVITSKY; WAY, 2010). A tese colocada nesse livro - e resgatada em Como as democracias morrem - é a de que, desde o fim da Guerra Fria, a instituição de regimes autoritários ocorre por vias democráticas.

Os últimos capítulos abordam o primeiro ano do governo Trump e a desintegração de normas democráticas, a qual permitiu a tentativa ou ascensão ao poder de outsiders que desafiam a continuidade do regime democrático. Os autores destacam, aqui, o papel das instituições informais na prevenção desse cenário. Enfatizam a importância de pilares democráticos, como a tolerância mútua entre os adversários políticos e a reserva institucional, que 
seria uma "subutilização do poder", ou seja, evitar ações que, mesmo dentro da lei, extrapolem os limites da civilidade e do "jogo limpo democrático".

A aplicação das regras informais já havia sido abordada por Levitsky na obra Informal Institutions and Democracy: Lessons from Latin America (2006). Embora trate do caso latino-americano, o robusto campo conceitual sobre essas questões permite compreender também a realidade norte-americana.

Importante notar que a classe trabalhadora aparece na obra como coadjuvante. Isso acontece porque a verdadeira proteção contra candidatos autoritários não é dada pelo comprometimento da população com os regimes democráticos, mas pelos "guardiões da democracia": os partidos e elites políticas. Cabe, portanto, a tais guardiões o esforço orquestrado de isolar e derrotar potenciais demagogos através da construção de uma frente única de oposição. Inclusive sistemas "demasiadamente democráticos" estão sujeitos à derrocada democrática, pois os líderes autoritários são populistas, figuras anti-establishment. Estes alegam representar "a voz do povo", porém ao chegarem ao poder tornam-se tiranos e subvertem a liberdade de repúblicas democráticas.

Para os autores foi, justamente, a influência dos cidadãos comuns na ascensão de Trump que possibilitou a sua candidatura, mesmo sem o apoio do establishment político. As elites políticas norte-americanas, portanto, perderam a sua função de guardiãs democráticas, o que abriu precedente para eleição de um candidato potencialmente autoritário.

Ainda que Levitsky e Ziblatt sejam extremamente críticos do governo Trump, seu livro tem o mérito de não restringir a análise a um viés ideológico. Deste modo, citam exemplos de líderes autoritários progressistas e conservadores, pois focam suas críticas essencialmente nas características antidemocráticas desses políticos. É necessário enfatizar também as sólidas análises, claramente fundamentadas por extensas pesquisas e reflexões, que justificam as 59 páginas que compõem a farta sessão de notas no fim do livro.

No entanto, as numerosas qualidades da obra de Levitsky e Ziblatt são acompanhadas por alguns problemas pontuais. Primeiro, para fazer comparações com a democracia estadunidense, os autores trabalham com exemplos de derrocadas democráticas de países que tinham e têm tal regime menos consolidado que o caso norte-americano, como Rússia, Turquia e 
Bélgica na década de 1930, ou o Chile dos anos 1970. Um segundo problema a ser apontado é que muitos exemplos usados pelos autores são de países que têm corrupção endêmica como uma forte característica dos seus processos políticos, algo que, embora afete a democracia devido à falta de transparência, não é amplamente abordado por Levitsky e Ziblatt.

O terceiro problema do texto é que os autores justificam a polarização política norte-americana dando um papel central à inclusão de minorias defendidas historicamente pelo Partido Democrata. Isso tornou o partido representante de liberais (na concepção norte-americana) e minorias e o distanciou dos brancos conservadores que compõem a base de massa do Partido Republicano. Entretanto, além de tal divisão já ser perceptível nos anos 1990, os autores não trazem para o centro dessa discussão elementos importantes que também contribuíram para a polarização política característica do cenário da eleição de Trump, como as mídias sociais.

No entanto, os problemas destacados não afetam a importância da obra, tampouco a sua ideia central (o enfraquecimento das instituições formais e informais na derrocada democrática). Esta se constitui, portanto, em um texto com debates essenciais frente ao cenário político atual. A leitura é recomendada a todos que buscam compreender a relevância do sistema democrático, os riscos que ele enfrenta e as consequências de seu declínio. Levitsky e Ziblatt, ao escreverem de forma simples, expandem o tema para não especialistas sem, contudo, perder profundidade, o que faz com que Como as democracias morrem seja importante também para os especialistas em política, ciências sociais e afins.

\section{REFERÊNCIAS BIBLIOGRÁFICAS}

1. BULLA, B. "Eleger presidente autoritário é risco à democracia", afirma professor de Harvard. O Estado de São Paulo, São Paulo, 23 jul. 2018. Disponível em: https://politica.estadao.com.br/noticias/eleicoes,eleger-presidente-autoritarioe-risco-a-democracia-avalia-professor-de-harvard,70002411332. Acesso em: 30 mai. 2019.

2. FERRAZ, R. Steven Levitsky: por que este professor de Harvard acredita que a democracia brasileira está em risco. BBC News Brasil, São Paulo, 19 out. 2018. 
Disponível em: https://www.bbc.com/portuguese/brasil-45829323. Acesso em: 30 mai. 2019.

3. FRABASILE, D. Como a polarização ameaça a democracia brasileira, segundo Steven Levitsky. Época Negócios, 23 out. 2018. Disponível em: https:// epocanegocios.globo.com/Brasil/noticia/2018/10/como-polarizacao-ameacademocracia-brasileira-segundo-steven-levitsky.html. Acesso em: 30 mai. 2019.

4. LAW, D. S.; VERSTEEG, M. The Declining Influence of the United States Constitution. New York University Review, v.87, 2012. Disponível em: https:// www.nyulawreview.org/wp-content/uploads/2018/08/NYULawReview-87-3Law-Versteeg_0.pdf. Acesso em: 25 mai. 2019.

Recebido em 01 de julho de 2019

Aceito em 18 de agosto de 2019 